\title{
Contemporary Approaches to the Qur'an and Sunnah
}

\author{
Mahmoud Ayoub (ed.)
}

Herndon, VA: IIIT, 2012. 230 pages.

This edited volume forms the first collection of proceedings from the Summer Institute for Scholars organized by the International Institute of Islamic Thought (IIIT), one of the publishers of this journal. This annual gathering, which was inaugurated in 2008, is "dedicated to the study of contemporary approaches to Qur'an and Sunnah," hence the name of this volume. Given the capacious title, the work naturally offers essays - ten to be precise - from a wide range of disciplines, including Qur'anic and hadith studies as well Islamic law, theology, history, and comparative religion. Being the first iteration of this series, it is perhaps somewhat unsurprising that the work's overall qual- 
ity is somewhat under par, with individual essays varying considerably in quality. It is therefore reassuring to see on IIIT's website that subsequent Summer Institutes have been given a more focused theme.

The work is divided into four parts: the first two focus in different ways on the Qur'an; the third part pertains more to the Sunnah and law (though, in my assessment, the ninth essay has more Qur'an in it than Sunnah); and part 4 consists of a single twelve-page essay on the history of Islamic studies in the West. Given constraints on space, I will not discuss every essay in this review.

The first essay, authored by Israr Ahmad Khan, suffers from a less-thanscholarly tone and sets out to accomplish in nineteen pages what most scholars would scarcely be able to do in a volume. Khan wishes to disabuse Islamic scholarship of the normative validity of any doctrine of abrogation (naskh) in the Qur'an - a very controversial thesis. But as the arguments appear to be mostly non sequiturs, he appears to arrive at his desired conclusion via proof by assertion. The bibliography seems woefully underpopulated, given the gargantuan task at hand, and there are noticeable omissions, such as Mustafa Zayd's magisterial two-volume work on the topic - perhaps the most comprehensive work ever written on this subject. In chapter 2, Aisha Y. Musa briefly sketches the Qur'anic meaning of jihad and qitāl and their morphological variants. She does this by analyzing the Qur'anic usage of these terms, and her short contribution provides some useful preliminary reflections on this issue that are worth pursuing further.

Part 2 begins with Mahmoud Ayoub's chapter on religious pluralism in the Qur'an, which provides an interesting modern reading of normative Islamic attitudes toward other religions. He seems to argue that an accurate intentionalist reading of the Qur'an results in a far more pluralist understanding of Islam than Muslims have historically allowed for. Like Khan's essay above, Ayoub's paper is intended as an ambitious corrective, and thankfully, unlike Khan's essay, its tone is scholarly. Its assertions regarding Qur'anic interpretation, however, need to be in dialogue with the Islamic tradition, given that they go against the understanding of the historical views of the vast majority of Muslim scholars. If he thinks Muslims cannot trust early Islamic exegetes' intentionalist interpretations of this aspect of Islamic theology, he could be asked why they should not also question their interpretation of other doctrines that are not explicitly in the Qur'an, such as the finality of the Prophet. The author's task may have been considerably easier had he chosen to undertake a reading of the Qur'an based on a readerresponse critical approach, borrowing from twentieth-century debates in literary theory. 
The next two essays, by Khaled Troudi and Mohammed Abu-Nimer, respectively, are similar. The latter discusses the status of Jews in the Qur'an in an important essay that reflects on the Qur'anic verses that are hostile toward Jews and Christians in the light of verses that are more favorable. An ecumenical desire to find Qur'anic justifications for religious pluralism animates this essay, like that of Ayoub, and similar criticisms apply.

Imad-ad-Dean Ahmad writes on a topic of considerable interest to me, but one in which mature Islamic reflections have yet to replace ones of a more apologetic vein, of which his essay is an example. Addressing the relationship between the Qur'an and science, Ahmad seems to suggest that modern science was born as a result of the Qur'anic worldview. It is not terribly clear to me where this impression comes from, and his essay will struggle to convince those familiar with the history of science that the Qur'an had any significant causative relation to the rise of modern science.

The final essay of part 2 is that of Daoud Nassimi, who undertakes a comparative analysis of several translations of the Qur'an in English and how they translate two sets of verses: one set pertaining to Friday prayers (Q. 62:9-11), and a second relating to verses pertaining to women's dress code (Q. 33:59 and 24:31). Some useful remarks are made concerning the fact that a translator of the Qur'an needs far more than a knowledge of Arabic to be equal to the task of translating accurately. However, the chapter suffers from a sense of excessive citation, since around fourteen of the essay's roughly thirty pages (pp. 124-29 and pp. 135-42) are taken up in extensive quotations from the various translations and other sources.

Sami Catovic's short essay, the first of part 3, attempts to develop a principled approach to matn analysis in hadith studies by building on traditional ideas found in works on the technical terms (muștalah) of hadith. (More recently, Jonathan A. C. Brown of Georgetown University has published in great detail on the rules of medieval matn analysis.) The penultimate chapter, by Mohammad Adam El Sheikh, is my favorite essay in the collection. Although it appears to be written by a non-native speaker of English, its content is both informative and edifying. Its author, a former judge of Shari'a courts in Sudan and a veteran arbitrator in Muslim communities in North America, provides the perspective of a scholar-practitioner of Islamic law and one who is concerned with preserving the rights of women who so frequently suffer at the hands of unscrupulous ex-husbands. The first part of the essay (pp. 172-86) argues, using exegetical and legal works, that "post-divorce financial support" (mut' 'at al-taläq) should be considered an obligation in the modern world. The second part (pp. 186-93) describes two North American case studies of hus- 
bands attempting to abuse some of the historical interpretations of this practice, and eventually failing to do so.

Khaleel Mohammad's short essay, which concludes this volume, seems unrelated to the overall theme but nevertheless provides some interesting reflections, from a Muslim perspective, of Western studies of Islam. Given the history of Orientalism and after the "catastrophe" of 9/11, the dramatic rise of Islamophobia in the media, which he notes, affects the discourse of the academy (p. 199).

Like all the works I have had the pleasure of reading from IIIT, this volume suffers from that most unforgiveable of lapses in academic publications - the absence of an index. This means that if one were to quickly read the work without taking extensive notes, one has to look for citations and noteworthy points using an unaided memory. This is not something I look forward to, should I ever need to turn back to this work years later in the course of subsequent research. If IIIT wishes for its publications to be afforded recognition in the academic mainstream, it cannot afford to publish monographs or edited volumes without any indexes.

One curious structural feature is the repetitive bibliography. Many chapters include a bibliography at the end, before the endnotes for that particular essay. Then there is an additional and more substantial bibliography at the end of the work, presumably composed of the contents of the shorter bibliographies. Sadly, the final bibliography seems to miss things listed in chapter bibliographies. The work by Ipgrave, mentioned in one of the chapter bibliographies (p. 75), does not appear in the final bibliography. There are other errors: Subhi Salih's name has been reversed in another chapter bibliography (p. 23), although it is correct in the final one. A single unified bibliography at the end may have helped avoid such errors, lent the work a less disjointed feeling, and probably reduced its environmental impact slightly - something to keep in mind for the future iterations of this series.

This volume represents the first of a series that is presently in its infancy. As the overall theme of the Summer Institute for Scholars is one that is worthy of study, one would have liked that its first publication set the standard for later years by being an exemplary work of scholarship, both in form and content. It appears that this task will have to be left to subsequent volumes in the series.

Usaama al-Azami

Ph.D. Candidate, Department of Near Eastern Studies Princeton University, Princeton, NJ 